\title{
BUDIDAYA KUDA LAUT DI DESA EKAS BUANA KECAMATAN JEROWARU KABUPATEN LOMBOK TIMUR
}

\author{
Dewi Nur'aeni Setyowati ${ }^{1 *}$, Nunik Cokrowati ${ }^{1)}$ \\ ${ }^{1)}$ Program Studi Budidaya Perairan, Universitas Mataram. \\ Jl. Majapahit No. 62 Mataram, 83125 \\ *korespondensi: dewinshuda@yahoo.com
}

\begin{abstract}
ABSTRAK
Desa Ekas Buana memilik potensi perikanan diantaranya penangkapan kuda laut. Harga jual kuda laut yang tinggi (Rp. 7.000.000,- per kg) dapat mendorong penangkapan berlebih terhadap komoditas ini. Pengetahuan budidaya kuda laut perlu dilakukan untuk mencegah kepunahan kuda laut dari penangkapan berlebih, selain itu dapat menjadi alternatif pendapatan di masyarakat Desa Ekas Buana. Kegiatan ini dilaksanakan di Desa Ekas Buana, Kecamtatan Jerowaru, Kabupaten Lombok Timur, Nusa Tenggara Barat. Metode pelaksanaan kegiatan meliputi sosialisasi, pelatihan kepada masyarakat, demplot budidaya kuda laut skala rumah tangga dengan demplot di mitra (budidaya kuda laut di akuarium dan di keramba jaring apung), serta pembinaan. Hasil demplot menunjukkan bahwa kuda laut lebih optimal dipelihara di keramba jaring apung.
\end{abstract}

Kata kunci : budidaya, Desa Ekas Buana, Kecamatan Jerowaru, kuda laut.

\section{PENDAHULUAN}

Masyarakat Desa Ekas Buana, Kecamatan Jerowaru, Kabupaten Lombok Timur, Provinsi Nusa Tenggara Barat merupakan masyarakat pesisir yang mengandalkan mata pencaharian dari hasil laut. Kegiatan perikanan yang berkembang di Desa Ekas Buana diantaranya adalah budidaya rumput laut, budidaya bawal bintang, serta penangkapan hasil-hasil perikanan. Kegiatan budidaya rumput laut sudah mengalami penurunan. Untuk tahun 2017, masyarakat yang memiliki keramba jarring apung melakukan budidaya bawal bintang. Budidaya bawal bintang memiliki kelemahan karena kebutuhan pakan yang tinggi. Sedangkan untuk kegiatan penangkapan ikan, sebelum diberlakukannya peraturan pemerintah tentang pelarangan bibit lobster, masyarakat melakukan penangkapan bibit lobster. Untuk tahun 2017, masyarakat mulai beralih kepenangkapan kuda laut karena kuda laut banyak ditemukan di perairan Desa Ekas Buana. Harga jual kuda laut hidup sebesar Rp. 15.000/ekor. Sedangkan harga kuda laut dari hasil pembelian masyarakat Desa Ekas Buana sebesar Rp. $5.500 .000 / \mathrm{kg}$ sedangkan di pasar online dapat mencapai Rp. 7.000.000,- per kg. Harga jual kuda laut yang tinggi dapat mendorong penangkapan kuda laut yang berlebihan, sehingga akan mengancam kelestarian kuda laut di perairan tersebut.

\section{METODE KEGIATAN}

Kegiatan pengabdian ini dilaksanakan di Desa Ekas Buana, Kecamatan Jerowaru, Kabupaten Lombok Timur. Pelaksanaan kegiatan pengabdian ini dilakukan mulai 
tanggal 21 April 2018 sampai dengan tanggal 25 Agustus 2018. Alat yang digunakan pada kegiatan ini adalah bak, akuarium, keramba jaring apung, aerator, pompa, penggaris, shelter dari ranting kayu, dan kamera. Sedangkan bahan yang digunakan pada kegiatan ini adalah kuda laut, air laut, serta artemia. Metode kegiatan meliputi:

1. Sosialisasi Program

Sosialisasi dilakukan kepada pemerintah desa dan juga masyarakat serta mitra. Sosialisasi bertujuan agar pemerintah desa mendukung kegiatan ini sehingga proses pendampingan dapat dilaksanakan. Sedangkan sosialisasi kepada masyarakat dan mitra bertujuan agar masyarakat serta mitra berpartisipasi aktif terhadap kegiatan PKM yang akan dilakukan.

2. Pelatihan Kelompok Masyarakat

Pelatihan bagi kelompok masyarakat bertujuan agar masyarakat mampu memahami tentang budidaya kuda laut sebagai landasan dalam menerapkan budidaya kuda laut. Materi yang akan diberikan meliputi Teknik Budidaya Kuda Laut (Sarana Prasarana yang Dibutuhkan, Padat Tebar, Pakan), Pemeliharaan Anakan Kuda Laut serta Pembesaran Kuda Laut di Keramba Jaring Apung serta Teknik Packing. Pemberian materi dilakukan menggunakan bahasa sederhana, dilengkapi dengan peraga yang akan memudahkan masyarakat memahami materi yang dijelaskan. Setelah materi diberikan, peserta diberi kesempatan untuk memberikan umpan balik sehingga tim dapat mengetahui permasalahan yang ada. Pelatihan juga menempatkan masyarakat sebagai subyek yang terlibat aktif dalam pelatihan tersebut.
3. Demplot Budidaya Kuda Laut Skala RumahTangga

Demplot kuda laut skala rumah tangga dilakukan pada mitra. Tim PKM akan memfasilitasi sarana prasarana yang diberikan untuk budidaya kuda laut skala rumah tangga di bak. Mitra terlibat dalam persiapan dan teknis pemeliharaan. Selain itu, mitra juga berperan dalam pembesaran kuda laut di keramba jarring apung dengan memanfaatkan keramba jarring apung yang sudah tersedia.

4. Pendampingan

Pendampingan bertujuan untuk memecahkan permasalahan dalam proses teknis pemeliharaan kuda laut sehingga mitra mampu menerapkan budidaya kuda laut dengan benar. Bentuk pendampingan adalah melalui hubungan jarak jauh dengan menggunakan media handphone, maupun dengan tim turun ke lokasi mitra secara berkala. Selain pendampingan dalam aspek produksi, tim juga akan membantu mencarikan pasar jika mitra kesulitan dalam melakukan penjualan produk kuda laut. Tim juga melakukan pendampingan dalam manajemen budidaya kuda laut skala rumah tangga.

\section{HASIL DAN PEMBAHASAN}

\section{Sosialisasi Program}

Sosialisasi program (peyuluhan) dilakukan di mitra pada tanggal 21 April 2018. Mitra menyambut baik kegiatan PKM yang akan dilakukan. Tim menjelaskan teknis kegiatan yang akan dilakukan kepada mitra. Perijinan dan sosialisasi kegiatan ke Kepala Desa Ekas Buana dilaksanakan pada tanggal 26 Juni 2018. 


\section{Pelatihan Kelompok Masyarakat}

Pelatihan bagi kelompok masyarakat bertujuan agar masyarakat mampu memahami tentang budidaya kuda laut sebagai landasan dalam menerapkan budidaya kuda laut. Kegiatan pelatihan dilaksanakan pada tanggal 30 Juni 2018. Peserta yang hadir sebanyak 27 orang.

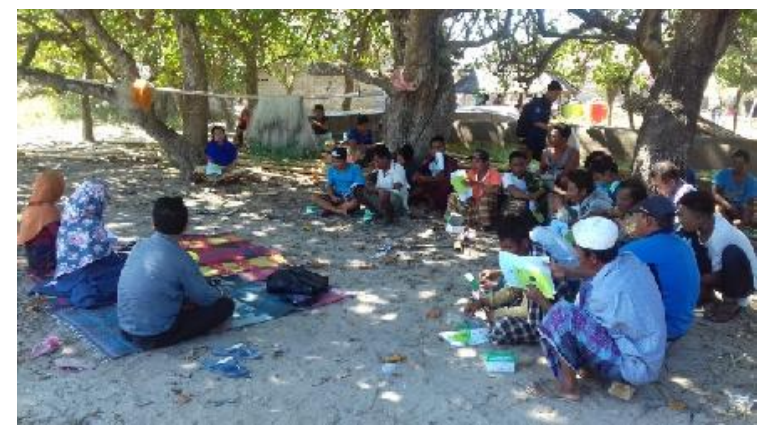

Gambar 1.PesertaPengabdian

Materi yang diberikan meliputi Teknik Budidaya Kuda Laut (SaranaPrasarana yang Dibutuhkan, Padat Tebar, Pakan), Pemeliharaan Anakan Kuda Laut serta pembesaran Kuda Laut di Keramba Jaring Apung. Pemberian materi dilakukan menggunakan bahasa sederhana, dilengkapi dengan peraga yang akan memudahkan masyarakat memahami materi yang dijelaskan. Alat peraga yang ditampilkan di peserta adalah bak untuk pemeliharaan anakan serta artemia, aerator untuk menyuplai oksigen pada bak pemeliharan serta artemia sebagai pakan ikan.

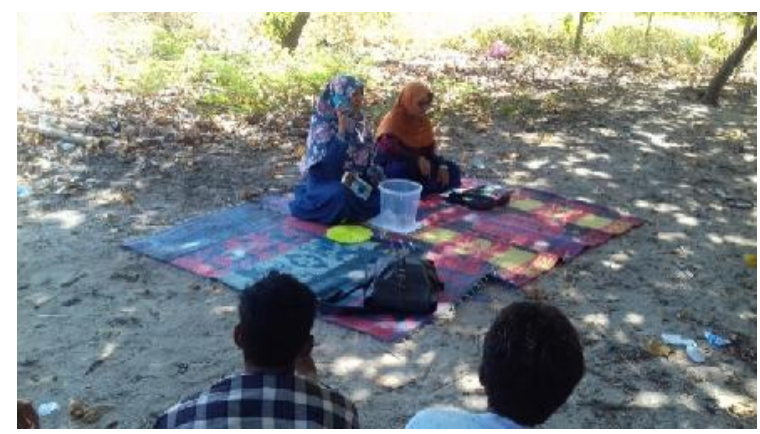

Gambar 2.Penjelasan dengan Alat Peraga
Setelah materi diberikan, peserta diberi kesempatan untuk memberikan umpan balik sehingga tim dapat mengetahui permasalahan yang ada. Pelatihan juga menempatkan masyarakat sebagai subyek yang terlibat aktif dalam pelatihan tersebut. Peserta menanyakan tentang tempat pembelian artemia sebagai pakan kuda laut. Tim pengabdian menjawab bahwa artemia dapat dibeli secara online maupun dapatdicari di toko di Mataram, selain itu tim pengabdian juga menawarkan untuk membantu dalam penyediaan suplai artemia. Pembudidaya juga menanyakan metode pemeliharaan di keramba jarring apung karena lebih cepat tumbuh. Selain itu pembudidaya juga menanyakan tentang penyakit putih dan penyakit perut kembung yang menyerang kuda laut. Peserta juga mengusulkan agar dapat di beripraktek budidaya kuda laut. Tim pengabdian menjelaskan bahwa setelah pelatihan akan ada praktek budidaya kuda laut di Desa Ekas Buana sehingga masyarakat dapat terlibat dalam pelaksanaan budidaya kuda laut.

\section{Pembuatan Demplot Budidaya Kuda Laut Skala Rumah Tangga}

Demplot kuda laut skala rumah tangga dilakukan pada mitra. Tim PKM memfasilitasi sarana prasarana yang diberikan untuk budidaya kuda laut skala rumah tangga di bak. Mitra terlibat dalam persiapan dan teknis pemeliharaan. Selain itu, mitra juga berperan dalam pembesaran kuda laut di keramba jarring apung dengan memanfaatkan keramba jaring apung yang sudah tersedia.

Demplot pemeliharaan kuda laut telah dilakukan di mitra dari mulai tanggal 25 Juli 2018. Pemeliharaan meliputi pemeliharaan induk kuda laut di bak, pemeliharaan anakan di akuarium pseudo kriesel, serta pemeliharaan kuda laut di keramba jaring apung. 


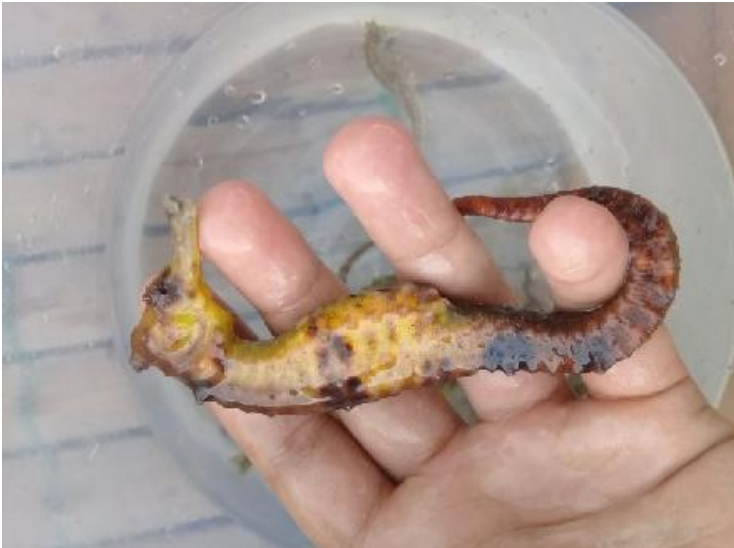

Gambar 3.IndukKudaLaut

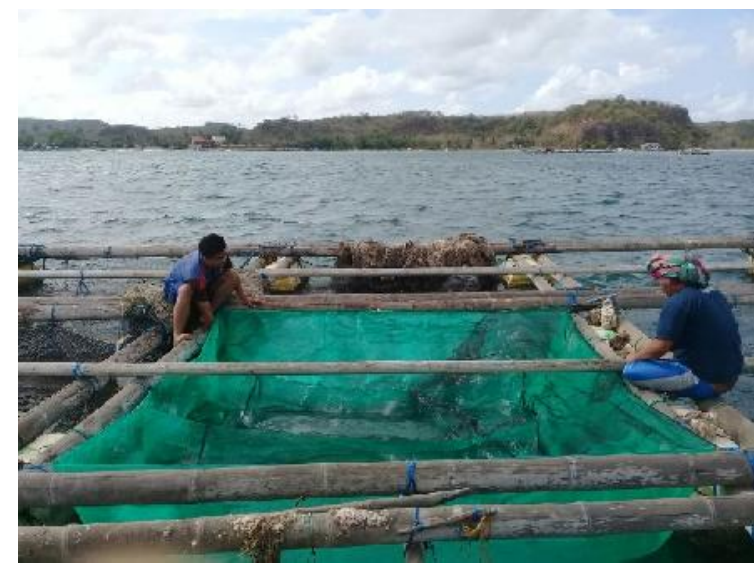

Gambar 4.PemeliharaanKudaLaut di kerambaJaringApung

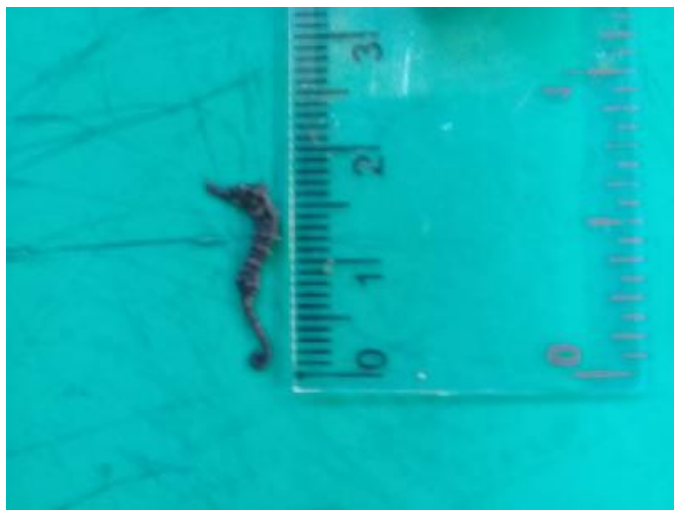

Gambar 5.AnakanKudaLaut

\section{Pendampingan}

Pendampingan bertujuan untuk memecahkan permasalahan dalam proses teknis pemeliharaan kuda laut sehingga mitra mampu menerapkan budidaya kuda laut dengan benar. Bentuk pendampingan adalah melalui hubungan jarak jauh dengan menggunakan media handphone, maupun dengan tim turun kelokasi mitra secara berkala. Selain itu, pendampingan juga dilakukan dengan tim pengabdian mengirimkan 3 orang mahasiswa Praktek Kerja Lapang (PKL) untuk melakukan kegiatan budidaya kuda laut selama sebulan dari mulai tanggal 25 Juli 2018 sampai dengan 25 Agustus 2018. Topik budidaya kuda laut yang dilakukan pendampingan dengan praktek di lapangan oleh mahasiswa adalah tentang pemeliharaan induk kuda laut di bak, pemeliharaan anakan kuda laut dengan menggunakan akuarium pseudo kriesel dan budidaya kuda laut di keramba jarring apung. Selain pendampingan dalam aspek produksi, tim juga akan membantu mencarikan pasar jika mitra kesulitan dalam melakukan penjualan produk kuda laut. Tim juga akan melakukan pendampingan dalam manajemen budidaya kuda laut skala rumah tangga.

\section{KESIMPULAN DAN SARAN}

Kegiatan budidaya kuda laut dapat dilakukan dengan skala rumah tangga menggunakan bak, akuarium dan keramba jaring apung.

Saran dari kegiatan ini adalah perlu dilakukan pendampingan intensif terhadap kegiatan budidaya kuda laut di Desa Ekas Buana agar masyarakat lebih mengerti tentang teknis budidayanya.

\section{DAFTAR PUSTAKA}

Cokrowati, N., Diniarti, N., Junaidi, M. 2015. Potensi Harmful Algal Blooms (Habs) Di Perairan Batu Nampar Lombok Timur. Laporan Penelitian PNBP. UniversitasMataram.

Kyi, T. S. 2015. Seahorse aquaculture in Viet Nam. World Aquaculture: 55-57. 
Setyowati, D. N., Diniarti, N., Waspodo, S. 2013. Budidaya Lobster (Panulirus homarus) dan Abalon (Haliotissp.) dengan Sistem Integrasi di Perairan Teluk Ekas.Jurnal Kelautan Vol. 6 No. 2 hal.137-141. 